\title{
Deep oxidation of methane over zirconia supported Ag catalysts
}

\author{
Lj. Kundakovic, M. Flytzani-Stephanopoulos ${ }^{*}$ \\ Department of Chemical Engineering, Tufts University, Medford, MA 02155, USA
}

Received 10 July 1998; accepted 29 January 1999

\begin{abstract}
Zirconia supported silver catalysts were studied for deep oxidation of methane. The catalyst structure was examined by XRD, XPS, STEM-EDX, HR-TEM and UV-Vis spectroscopy and related to the catalyst activity. Methane conversion strongly depends on $\mathrm{Ag}$ state and dispersion. At low Ag loading $(<2$ at $\%)$, small Ag particles $(<5 \mathrm{~nm})$ have low activity. The turnover frequency for methane oxidation increases as the Ag particle size increases from 5 to $10 \mathrm{~nm}$ as determined from HRTEM, while the activation energy remains the same. Ag ion-exchanged ZSM-5 zeolite materials, containing Ag in highly dispersed state as isolated $\mathrm{Ag}^{+}$were studied for comparison. High conversion of methane was found only in zeolite catalysts containing a large amount of silver, some of which was in particle form. The reaction rate on zirconia-supported $\mathrm{Ag}$ particles is 0.77 order in methane and 0.37 order in oxygen. The reaction products, carbon dioxide and water, do not affect the methane oxidation rate in levels up to of 1.7 and $3.5 \mathrm{~mol} \%$ in the feedgas, respectively. The active phase under reaction conditions for both low and high Ag loading is the oxygen covered metallic Ag surface, as was confirmed by XPS and UV-Vis spectrometry. (C) 1999 Elsevier Science B.V. All rights reserved.
\end{abstract}

Keywords: Methane oxidation; Structure sensitivity; Silver; Particle size

\section{Introduction}

Natural gas is an attractive energy source as it is the cleanest burning fossil fuel, due to its low carbon content and negligible $\mathrm{SO}_{2}$ emissions. The exhaust gas from natural gas burning sources (gas turbines or natural gas vehicles) contains unconverted methane in addition to large amounts of $\mathrm{CO}_{2}$ and $\mathrm{H}_{2} \mathrm{O}$. Methane emissions currently are not regulated, but they may become regulated in the near future. Noble metalbased catalysts (Pd, Pt, Rh), while active for methane oxidation are not adequate for these applications due

\footnotetext{
*Corresponding author. Tel.: +1-6176273048; fax: +16176273991; e-mail: mstephanopoulos@infonet.tufts.edu
}

primarily to high light-off temperature and their high cost.

The most active catalysts for methane oxidation are Pd-based catalysts [1]. These have been extensively studied [2-11] for both high temperature, catalytic combustion of methane and for low temperature, complete oxidation. However, the nature of active sites, complex $\mathrm{Pd} / \mathrm{PdO}$ chemistry during methane oxidation and structure sensitivity are still not well understood. The catalytic chemistry of Pd-based materials is further complicated by the $\mathrm{Pd} / \mathrm{PdO}$ transformation under reaction conditions, which results in the activation/deactivation of the catalyst. In addition, Pdbased materials give partial oxidation products $\left(\mathrm{H}_{2}\right.$ and $\mathrm{CO}$ ) under reducing conditions [12]. Methane 
oxidation over Pd based materials is found to be firstorder in methane, zero-order in oxygen $[13,14]$ and is inhibited by the presence of reaction products, water (negative first-order) and $\mathrm{CO}_{2}$ (negative second-order) [4]. Methane oxidation appears to be sensitive to the oxidation state of palladium. It is generally accepted that the active phase under oxygen-rich conditions is $\mathrm{PdO}$. The PdO phase spread on the support (zirconia or alumina) is less active than $\mathrm{PdO}$ formed on the surface of Pd particles [4]. Some authors have reported that the reaction is independent of particle size [4], while others have found that turnover rates increase with particle size [13,14]. Fujimoto et al. [14] suggested that the formation of stronger $\mathrm{Pd}-\mathrm{O}$ bonds in small $\mathrm{PdO}$ crystallites is a reason for their lower activity. Highly dispersed Pd (as in zeolite matrix) at low Pd loading is found to be a poor methane oxidation catalyst $[15,16]$. However, at high metal loading, Pd-exchanged zeolite catalysts show high methane oxidation activity $[15,16]$. Similarly, highly dispersed Pt had lower activity for methane oxidation than larger Pt particles [17].

$\mathrm{Ag}$ is next to Pd in the Periodic Table, and is expected to have similar chemical properties. However, $\mathrm{Ag}$ is known to be a good partial oxidation catalyst (e.g. for methanol oxidation to formaldehyde, ethylene epoxidation) [18-22]. Oxygen adsorption on single crystal Ag surfaces, as well as on polycrystalline, supported Ag particles has been studied extensively [23,24]. Different oxygen species have been detected as a result of oxygen adsorption on silver [19,20,25-27], some of which are responsible for partial, and some for complete oxidation reactions. Depending on temperature, oxygen adsorbs dissociatively on silver surfaces [23,24,28-31] and its adsorption is followed by the formation of oxide and subsurface oxygen [25,32]. Oxygen-covered Ag surfaces were found to be more reactive than clean metal surfaces. For example, while CO does not react with clean Ag surfaces, it reacts readily at room temperature to form $\mathrm{CO}_{2}$ with oxygen-covered silver surfaces [32]. However, the role of various oxygen species in oxidation reactions is not well understood. The importance of adsorbed oxygen species and metal/metal oxide redox behavior in $\mathrm{Pd}$ reactivity for complete methane oxidation has been demonstrated for $\mathrm{Pd}$ catalysts [33]. Similarly, oxygen adsorption and oxide formation on silver is expected to play an important role, when $\mathrm{Ag}$ is used as an alternative to Pd-based catalysts.

Recently, Ag ion-exchanged zeolites and Ag supported on alumina have received attention as catalysts for the lean reduction of $\mathrm{NO}_{x}$ by hydrocarbons [3437]. It has been found that low-content $\mathrm{Ag} / \mathrm{Al}_{2} \mathrm{O}_{3}$ are effective catalysts for the selective reduction of $\mathrm{NO}$ with hydrocarbons, while their activity dramatically decreases as the Ag loading increases [38]. This drop in activity has been attributed to the increased rate of hydrocarbon combustion at higher Ag loading, but the reasons for the observed behavior are not clear. Related to this is the observed dependence of the ethylene epoxidation rate on $\mathrm{Ag}$ particle size [39]. The ethylene epoxidation rate increases as silver particle size increases above $50 \mathrm{~nm}$ [39]. Also, the ethylene oxide deep oxidation rate to carbon dioxide is higher on small Ag particles $(16 \mathrm{~nm})$ than on large $(100 \mathrm{~nm})$ particles [40]. Even though the particle size effects on reactivity and selectivity in ethylene epoxidation are still not well understood, it is believed that they are related to the oxygen adsorption properties of silver particles as well as their structure and the presence of defects on the surface [40].

In this study, the structure and activity of $\mathrm{Ag}$ supported on zirconia for the complete oxidation of methane were examined. These materials were found to catalyze the complete oxidation of methane at temperatures higher than $350^{\circ} \mathrm{C}$. The catalyst structure was studied by XRD, HRTEM and STEM/EDX. Oxygen chemisorption was used to measure the dispersion of silver, while the oxidation state of silver was examined by XPS and UV-Vis spectrometry. Complete kinetic studies were performed. The aim of this study was to obtain a better understanding of $\mathrm{Ag} / \mathrm{Ag}$-oxide chemistry for methane oxidation as a function of the $\mathrm{Ag}$ dispersion, and $\mathrm{Ag}$ oxidation state. The activity of different $\mathrm{Ag}$ species for the complete oxidation of methane is discussed.

\section{Experimental}

\subsection{Catalyst preparation and characterization}

The zirconia used here was prepared from zirconium hydroxide (MEL Chemicals, batch No. 96-0801). This $\mathrm{ZrO}_{2}$ had a BET surface area of $36.3 \mathrm{~m}^{2} / \mathrm{g}$ 
after a $650^{\circ} \mathrm{C}$-heat treatment in air for $8 \mathrm{~h}$. Zirconia powders had the monoclinic and tetragonal crystal structure after the $650^{\circ} \mathrm{C}$-heat treatment in air.

Supported Ag catalysts were prepared by the incipient wetness impregnation method using the calcined supports prepared as above. The required amount of ammonia solution of $\mathrm{AgNO}_{3}$ was added dropwise to the support powder under constant stirring. The wet powder was degassed in vacuum for $1 \mathrm{~h}$ so that the solution fully filled the pores of the support. The samples were dried at $100^{\circ} \mathrm{C}$ overnight and calcined typically at $650^{\circ} \mathrm{C}$ for $8 \mathrm{~h}$ (heating rate $2^{\circ} \mathrm{C} / \mathrm{min}$ ). To prepare the catalysts with higher silver content the impregnation procedure was repeated several times. The catalyst composition throughout the paper is expressed as atomic\% (metal/total metals $\times 100 \%$ ). The properties of $\mathrm{Ag}$ catalysts used in this study are listed in Table 1. Ag-containing catalysts had a lower BET surface area $\left(<30 \mathrm{~m}^{2} / \mathrm{g}\right)$ than the zirconia support used. Pore closure of zirconia due to the impregnation is evident.

Silver dispersion was measured by oxygen chemisorption in a Micromeritics PulseChemiSorb 2705 instrument. Typically, $0.1 \mathrm{~g}$ of catalyst was reduced at $170^{\circ} \mathrm{C}$ in a flow of $10 \% \mathrm{H}_{2} / \mathrm{He}$ for $1 \mathrm{~h}$ and degased at $300^{\circ} \mathrm{C}$ for $1.5 \mathrm{~h}$. Oxygen uptake was then measured at $170{ }^{\circ} \mathrm{C}$ by injecting pulses of $20 \% \mathrm{O}_{2} / \mathrm{He}$. The $\mathrm{Ag}$ dispersion was calculated based on 1:1 Ag:O stoichiometry [30,41,42]. The particle size based on the chemisorption measurements was calculated from the expression $d_{\mathrm{p}}(\mathrm{nm})=117.7 / D$, where $d_{\mathrm{p}}$ is the particle diameter (assuming hemispherical particles) and $D$ the \%dispersion [43]. The surface density of $\mathrm{Ag}$ atoms used in the calculation was $1.15 \times 10^{19}$ atoms/ $\mathrm{m}^{2}$ [43].

$\mathrm{Ag}$ ion-exchanged Na-ZSM-5 ( $\mathrm{Si} / \mathrm{Al}=21.5$, Davison division, W.R. Grace and Co., lot No. SMR 62826-1192) was prepared by a $24 \mathrm{~h}$ long ion exchange at room temperature in the dark using dilute aqueous solutions of Ag-nitrate [34]. Samples were filtered, washed and dried at $100^{\circ} \mathrm{C}$ for $8 \mathrm{~h}$. Samples were then heat treated in air at $500^{\circ} \mathrm{C}$ for $2 \mathrm{~h}$. For bulk composition analysis, the powder was dissolved in HF, diluted with deionized water and the resulting solution was analyzed by inductively coupled plasma (ICP) atomic emission spectrometry (Perkin Elmer Plasma 40).

$\mathrm{X}$-ray powder diffraction (XRD) analysis of catalyst samples was performed on a Rigaku 300 X-ray diffractometer with rotating anode generators and monochromatic detector. Copper $\mathrm{K}_{\alpha}$ radiation was used with power setting at $60 \mathrm{kV}$ and $300 \mathrm{~mA}$. For crystal phase identification, the typical operation parameters were: divergence slit of $1^{\circ}$, scattering slit $1^{\circ}$, receiving slit $0.3^{\circ}$, and a scan rate of $2-5^{\circ} / \mathrm{min}$ with $0.02^{\circ}$ data interval.

The catalyst microstructure analysis was performed on a Vacuum Generators HB603 scanning transmission electron microscope (STEM) equipped with an $\mathrm{X}$-ray microprobe of $0.14 \mathrm{~nm}$ optimum resolution for energy dispersive X-ray analysis (EDX). For STEM analysis, the catalyst powder was dispersed on a copper grid coated with a carbon film and elemental

Table 1

Physical properties of zirconia-supported Ag catalysts

\begin{tabular}{llllcl}
\hline Catalyst & $\begin{array}{l}\text { Surface } \\
\text { area }^{a}\left(\mathrm{~m}^{2} / \mathrm{g}\right)\end{array}$ & $\begin{array}{l}D \\
(\%)^{\mathrm{d}}\end{array}$ & $\begin{array}{l}d_{\mathrm{p}}(\mathrm{nm}) \text { by } \mathrm{O}_{2} \\
\text { chemisorption }\end{array}$ & $\begin{array}{l}d_{\mathrm{p}}(\mathrm{nm}) \text { by } \\
\text { HR-TEM }\end{array}$ & $\begin{array}{l}d_{\mathrm{p}}(\mathrm{nm}) \\
\text { by XRD }\end{array}$ \\
\hline $1 \% \mathrm{Ag} / \mathrm{ZrO}_{2}$ & 28.7 & 22.9 & 5.1 & $5.3(5.6)^{\mathrm{c}}$ & $5.1(5.2)^{\mathrm{c}}$ \\
$2 \% \mathrm{Ag} / \mathrm{ZrO}_{2}$ & 30.1 & 20.4 & 5.8 & - & n.d. \\
$3.5 \% \mathrm{Ag} / \mathrm{ZrO}_{2}{ }^{\mathrm{b}}$ & 22.1 & 12.8 & 9.2 & $11.0(13.2)^{\mathrm{c}}$ & 30.0 \\
$5.0 \% \mathrm{Ag} / \mathrm{ZrO}_{2}{ }^{\mathrm{b}}$ & 21.0 & 12.7 & 9.3 & - & - \\
$5.0 \% \mathrm{Ag} / \mathrm{ZrO}_{2}$ & 19.7 & 10.8 & 11.0 & - & - \\
$6.5 \% \mathrm{Ag} / \mathrm{ZrO}_{2}{ }^{\mathrm{b}}$ & 20.8 & 7.7 & 15.2 & - & - \\
$7.9 \% \mathrm{Ag} / \mathrm{ZrO}_{2}{ }^{\mathrm{b}}$ & 21.3 & 6.5 & 18.2 & - & - \\
$8.0 \% \mathrm{Ag} / \mathrm{ZrO}_{2}$ & 19.7 & 5.1 & 23.0 & & - \\
\hline
\end{tabular}

\footnotetext{
${ }^{\mathrm{a}}$ BET-N $\mathrm{N}_{2}$ desorption porosimetry.

${ }^{\mathrm{b}}$ Prepared by successive impregnation with dilute aqueous solution of $\mathrm{AgNO}_{3}$.

${ }^{\mathrm{c}}$ Surface averaged (volume averaged).

${ }^{\mathrm{d}}$ Dispersion, calculated from oxygen chemisorption.

n.d.: not detected.
} 
maps were obtained on a $128 \times 128$ data matrix. HRTEM analysis was performed on a JEOL 2010 instrument. For the TEM analysis, powder was dispersed in isopropyl alcohol using the ultrasonic bath and deposited on a carbon coated 200 mesh $\mathrm{Cu}$ grid.

The catalyst surface composition was determined by X-ray photoelectron spectroscopy (XPS) on a Perkin Elmer 5100 system. For XPS analysis, the catalyst powder was pressed on a copper foil and placed in the vacuum chamber without any pretreatment. An Al X-ray source was used with the power setting at $300 \mathrm{~W}$. The binding energy was adjusted to the $\mathrm{C} 1 \mathrm{~s}$ peak at $284.6 \mathrm{eV}$, which existed in all measurements.

UV-Vis diffuse reflectance spectra were recorded on a Hewlett Packard 8052A diode array spectrophotometer ( $2 \mathrm{~nm}$ spectral resolution) equipped with a diffuse reflectance attachment (DRA) (Harrick). A stainless steel reaction chamber with silica windows was used in conjunction with the DRA for measurements under controlled-gas atmosphere and temperatures up to $600^{\circ} \mathrm{C}$. $\mathrm{MgO}$ powder $(99.99 \%$, Aldrich) was used as a reference. DR spectra were recorded under oxidizing $\left(20 \% \mathrm{O}_{2} / \mathrm{He}\right)$ and reducing $(10 \%$ $\mathrm{H}_{2} / \mathrm{He}$ ) conditions.

\subsection{Activity tests}

All catalysts were tested in a laboratory-scale packed-bed flow reactor, which consisted of $1 \mathrm{~cm}$ I.D. $\times 50 \mathrm{~cm}$ long quartz tube with a porous quartz frit placed at the middle. An electric furnace (Lindberg) was used to heat the reactor. Temperature was monitored by a K-type thermocouple placed at the top of the catalyst bed, and controlled by a Wizard temperature controller. The flow of reacting gases was measured by mass flow meters. The typical feed gas was $1 \% \mathrm{CH}_{4}, 8 \% \mathrm{O}_{2}$, balance $\mathrm{He}$, for methane oxidation activity tests. All gases were certified calibration gas mixtures. The catalyst loading was $150 \mathrm{mg}$, unless otherwise noted. The pressure drop through the reactor was $<2$ psi, so that all experiments were carried out at nearly atmospheric pressure. The catalysts were tested as prepared without any pretreatment (particle size $<153 \mu \mathrm{m}$ ), and activity measurements were conducted in ascending temperature mode, so that lightoff behavior could be recorded. In some experiments, the activity was measured in descending manner to check for possible deactivation or hysteresis. A fixed contact time of $0.09 \mathrm{~g} \mathrm{~s} / \mathrm{cm}^{3}$ (STP) (corresponding to a gas hourly space velocity, GHSV, of $72000 \mathrm{~h}^{-1}$ ) was used in these experiments, unless otherwise noted. The product gas stream was analyzed by an HP 5880A gas chromatograph equipped with a $1 / 4$ in. carbosphere column (for $\mathrm{CO}, \mathrm{CO}_{2}$ and $\mathrm{CH}_{4}$ separation) and a thermal conductivity detector. The carrier gas was helium at a flow rate of $30 \mathrm{~cm}^{3} / \mathrm{min}$. The injector, oven and detector temperatures were set at $90^{\circ} \mathrm{C}, 90^{\circ} \mathrm{C}$ and $150^{\circ} \mathrm{C}$, respectively.

For kinetic measurements, the reactor was operated in differential mode, with the conversion not exceeding $10 \%$. The catalyst was diluted by a silicon carbide powder 5-20 times to achieve low contact times and avoid heat and mass-transfer limitations. The particle size used in the kinetic experiments was $<50 \mu \mathrm{m}$. The reaction rate dependence on methane was measured in a gas mixture containing $0.3-5.7 \% \mathrm{CH}_{4}$ and $5 \% \mathrm{O}_{2}$, balance helium. Similarly, the reaction rate order in $\mathrm{O}_{2}$ was measured at $1 \% \mathrm{CH}_{4}$ and $0.5-8 \% \mathrm{O}_{2}$, balance helium. To check for $\mathrm{H}_{2} \mathrm{O}$ and $\mathrm{CO}_{2}$ inhibition effects, the rate dependence on $\mathrm{H}_{2} \mathrm{O}$ and $\mathrm{CO}_{2}$ was measured in $1 \% \mathrm{CH}_{4}, 5 \% \mathrm{O}_{2}, 0.3-3.5 \% \mathrm{H}_{2} \mathrm{O}$ and $1 \% \mathrm{CH}_{4}, 5 \% \mathrm{O}_{2}$, $0.3-1.7 \% \mathrm{CO}_{2}$, respectively.

\section{Results}

\subsection{Activity tests}

The catalysts used in this study and their physical properties are listed in Table 1. All materials had a surface area lower than $30 \mathrm{~m}^{2} / \mathrm{g}$, and dispersion lower than $50 \%$. Light-off curves of several $\mathrm{Ag} / \mathrm{ZrO}_{2}$ catalysts for the complete oxidation of methane at the contact time of $0.09 \mathrm{~g} \mathrm{~s} / \mathrm{cm}^{3}$ are shown in Fig. 1. Zirconia-supported silver catalysts are active for the complete oxidation of methane at temperatures higher than $300^{\circ} \mathrm{C}$. The silver loading has a strong effect on the activity. As the Ag loading increases from 1 to 3.5 at $\%$, the temperature for $50 \%$ conversion of methane shifts from $650^{\circ} \mathrm{C}$ to $480^{\circ} \mathrm{C}$, respectively. Further increase of Ag loading up to 7.9 at $\%$ does not change the catalyst performance. A strong effect of Ag dispersion on the catalyst activity for methane oxidation is evident. 


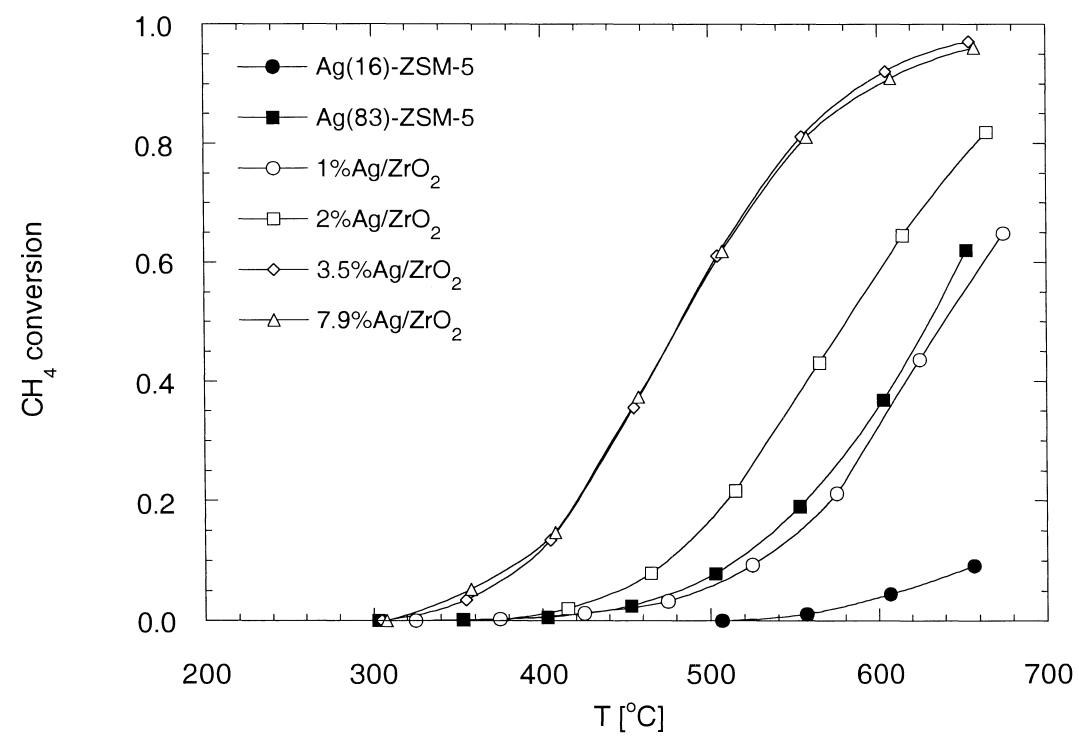

Fig. 1. Light-off curves for deep oxidation of methane over various Ag-containing catalysts $\left(1 \% \mathrm{CH}_{4}, 8 \% \mathrm{O}_{2}\right.$, balance $\mathrm{He} ; 0.09 \mathrm{~g} \mathrm{~s} / \mathrm{cm}^{3}(\mathrm{STP})$, $\left.\mathrm{SV}=72000 \mathrm{~h}^{-1}\right)$.

To further examine the effect of the Ag oxidation state and dispersion on the catalytic activity for methane oxidation, $\mathrm{Ag}$ ion-exchanged ZSM-5 materials, which contain silver in highly dispersed state were compared to $\mathrm{Ag} / \mathrm{ZrO}{ }_{2}$ catalysts. At low $\mathrm{Ag}$ loading as in $\mathrm{Ag}(16)-\mathrm{ZSM}-5(1.2 \mathrm{wt} \% \mathrm{Ag})$, the activity is low, giving $10 \%$ conversion of methane at $650^{\circ} \mathrm{C}$ (Fig. 1). A high Ag-containing sample (Ag(83)-ZSM-5; $5.9 \mathrm{wt} \% \mathrm{Ag}$ ) shows activity similar to that of the 1 at $\% \mathrm{Ag} / \mathrm{ZrO}{ }_{2}$ catalyst (Fig. 1). The reason for such differences in activity must be related to the different catalyst structure on the two supports. In Ag-ZSM-5 catalysts, silver is primarily present as isolated ions [44]. Isolated $\mathrm{Ag}^{+}$ions in $\mathrm{Ag}(16)-$ ZSM-5 have poor activity for methane oxidation. At higher $\mathrm{Ag}$ loading, the formation of $\mathrm{Ag}$ clusters, which have different specific activity has also been observed [44]. On the other hand, silver in $\mathrm{ZrO}_{2}$ supported catalysts is mainly present as $\mathrm{Ag}$ particles. Both Ag ion-exchanged ZSM-5 and $\mathrm{Ag} / \mathrm{ZrO}_{2}$ catalysts are complete oxidation catalysts under the methanelean conditions employed here. For all catalysts used in this study the only oxidation products observed were $\mathrm{CO}_{2}$ and $\mathrm{H}_{2} \mathrm{O}$ in the temperature range studied $\left(<650^{\circ} \mathrm{C}\right)$. No partial oxidation products, such as $\mathrm{CO}$ or $\mathrm{H}_{2}$, were detected, even with $\mathrm{CH}_{4}$-rich gas mixtures.
In separate kinetic experiments, the methane oxidation rate over $\mathrm{Ag} / \mathrm{ZrO}_{2}$ catalysts was measured by operating the reactor in the differential mode, with the conversion kept below $10 \%$. Turnover rates for methane oxidation were calculated based on the exposed Ag measured by oxygen chemisorption (Table 1). Fig. 2 shows dependence of the turnover frequency and apparent activation energy on $\mathrm{Ag}$ particle size determined from oxygen chemisorption on various $\mathrm{Ag} / \mathrm{ZrO}{ }_{2}$ catalysts. A strong dependence of the methane oxidation turnover frequency on crystallite size occurs at a size lower than $10 \mathrm{~nm}$. Thus, the turnover frequency increased four times as the $\mathrm{Ag}$ particle size increased from 5 to $10 \mathrm{~nm}$ (Fig. 2). As the particle size increases above $8 \mathrm{~nm}$, the turnover frequency increases slowly. At the same time, the apparent activation energy remains the same $(67.5 \pm 4.4 \mathrm{~kJ} /$ mol). Only for 1 at $\% \mathrm{Ag} / \mathrm{ZrO}_{2}$ was a higher apparent activation energy measured $(94.1 \pm 3.7 \mathrm{~kJ} / \mathrm{mol})$. The apparent turnover frequency for methane oxidation over Ag ion-exchanged ZSM-5 catalysts is much lower $\left(0.0006 \mathrm{~s}^{-1}\right.$ for $\mathrm{Ag}(83)-\mathrm{ZSM}-5$, and 0.00056 for $\mathrm{Ag}(18)-\mathrm{ZSM}-5$ at $500^{\circ} \mathrm{C}$ [44]), calculated on the basis of total Ag content assuming 100\% Ag dispersion.

The orders of methane oxidation rate in methane and oxygen partial pressures for the $\mathrm{Ag} / \mathrm{ZrO} \mathrm{C}_{2}$ cata- 


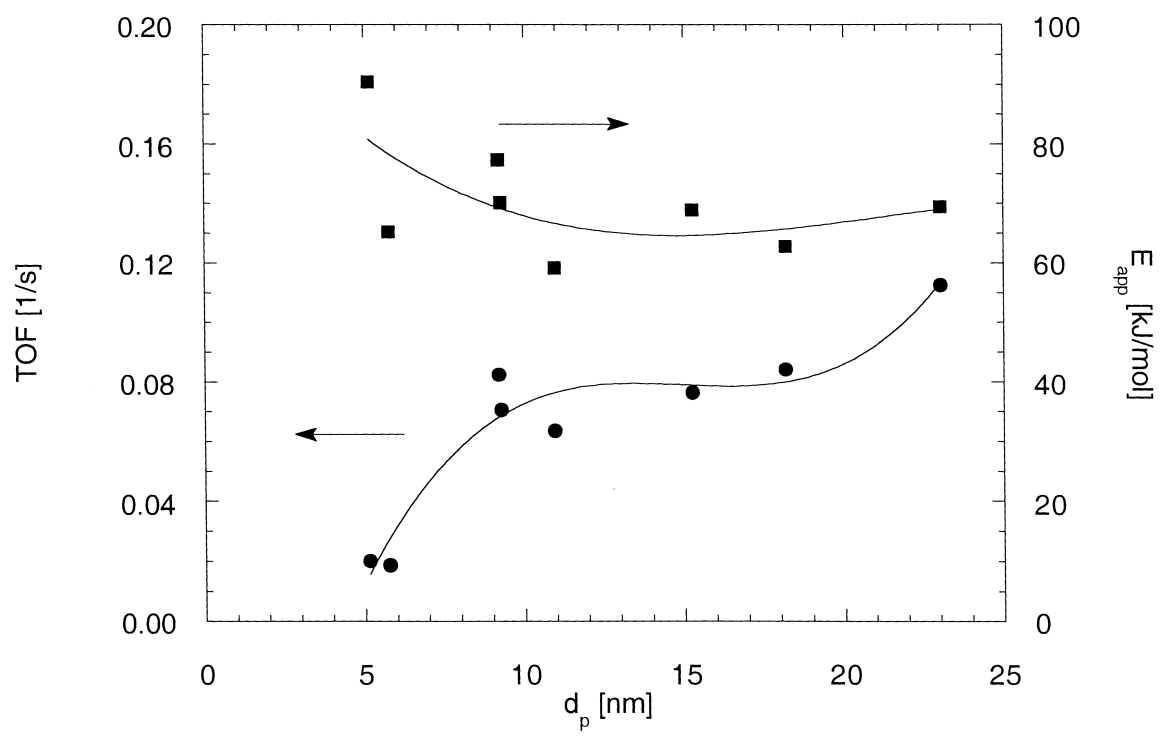

Fig. 2. Particle size effect on the turnover frequency (TOF) and apparent activation energy $\left(E_{\text {app }}\right)$ of methane oxidation for $\mathrm{Ag} / \mathrm{ZrO} \mathrm{O}_{2}$ catalysts in $1 \% \mathrm{CH}_{4}, 5 \% \mathrm{O}_{2}$ at $500^{\circ} \mathrm{C}$; TOF $\left(\mathrm{s}^{-1}\right)$ is the rate normalized by the amount of exposed $\mathrm{Ag}$.

lysts, found from the kinetic measurements are shown in Figs. 3 and 4, respectively. The reaction order in methane was found to be $0.77 \pm 0.06$, and the reaction order in oxygen $0.37 \pm 0.1$. The apparent activation energy was $E=79.5 \mathrm{~kJ} / \mathrm{mol}$ and the apparent pre- exponential factor was $A=1.9 \times 10^{8} \mu \mathrm{mol} / \mathrm{g} / \mathrm{s} / \mathrm{bar}^{1.5}$ for the $5 \% \mathrm{Ag} / \mathrm{ZrO}_{2}$ catalyst. The reaction order in oxygen partial pressure over the $2 \% \mathrm{Ag} / \mathrm{ZrO}_{2}$ material was also 0.37 at $550^{\circ} \mathrm{C}$ (data not shown). Fig. 5 shows that methane oxidation on $\mathrm{Ag} / \mathrm{ZrO}_{2}$ catalysts is not

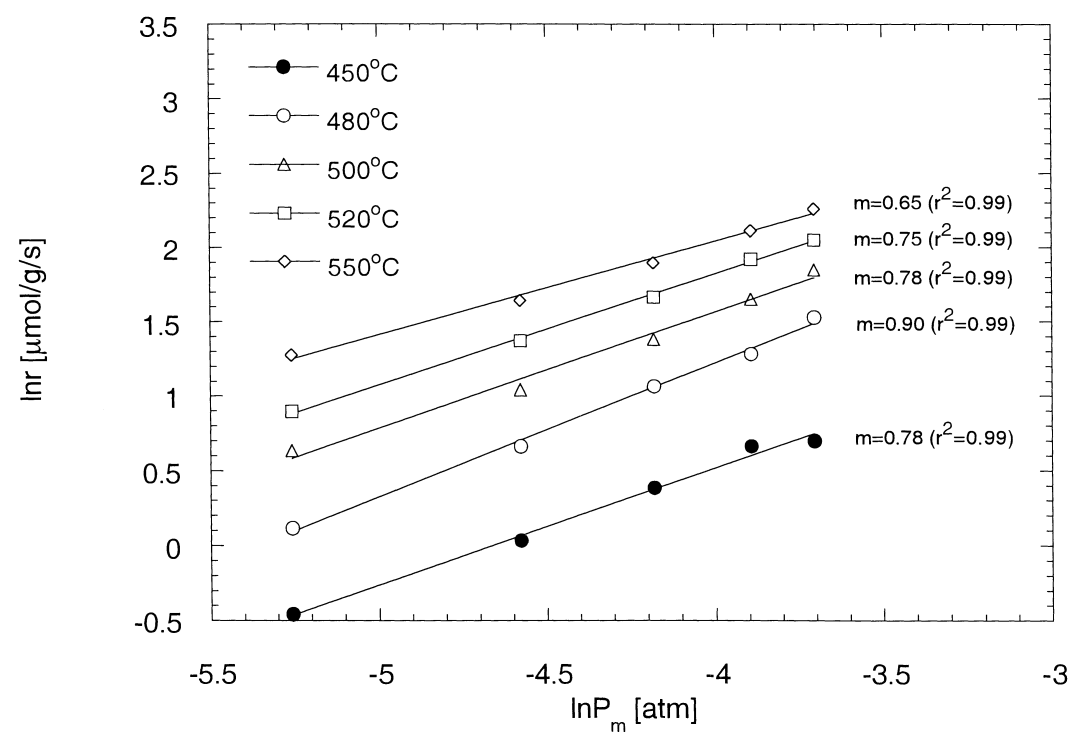

Fig. 3. Methane oxidation rate as a function of methane partial pressure over 5 at $\% \mathrm{Ag} / \mathrm{ZrO}_{2}$ at $10 \% \mathrm{O}_{2}\left(0.012 \mathrm{~g} \mathrm{~s} / \mathrm{cm}^{3}(\mathrm{STP})\right)$. 


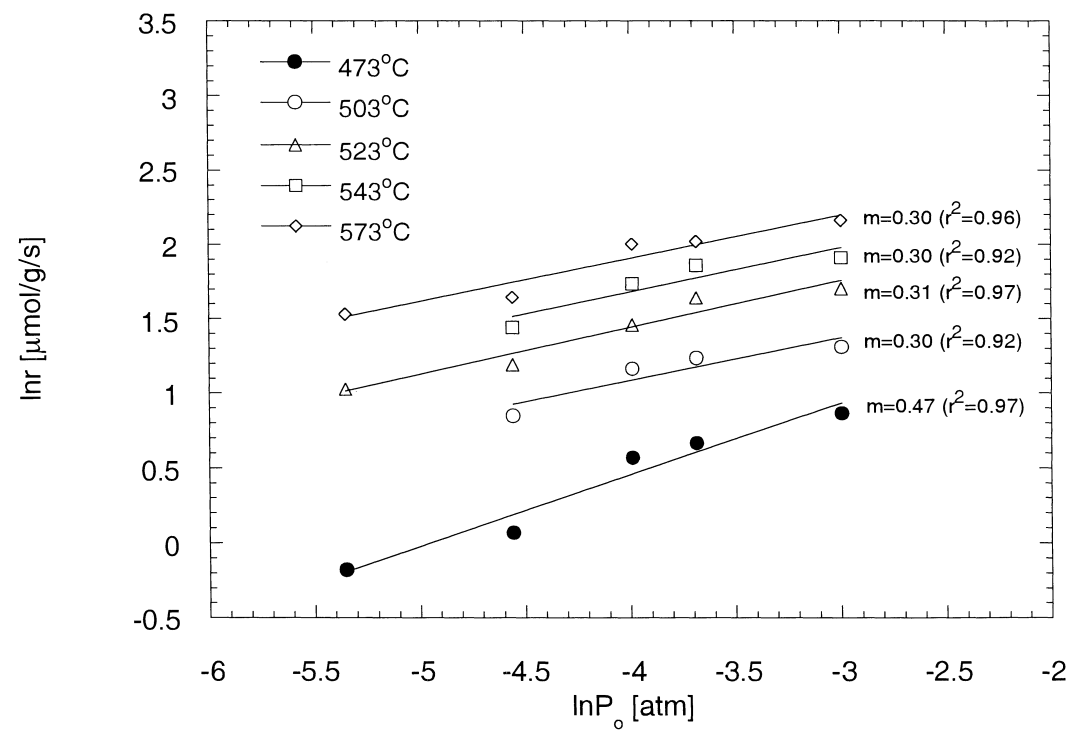

Fig. 4. Methane oxidation rate as a function of oxygen partial pressure over 5 at $\% \mathrm{Ag} / \mathrm{ZrO}_{2}$ at $1 \% \mathrm{CH}_{4}\left(0.012 \mathrm{~g} \mathrm{~s} / \mathrm{cm}^{3}(\mathrm{STP})\right)$.

sensitive to water and carbon dioxide concentration up to $3.8 \%$ and $1.8 \%$, respectively. Almost zero-order dependence on the partial pressure of $\mathrm{H}_{2} \mathrm{O}$ and $\mathrm{CO}_{2}$ was observed at $500^{\circ} \mathrm{C}$. Moreover, $\mathrm{H}_{2} \mathrm{O}$ did not affect the catalyst activity even at higher $(5 \mathrm{~mol} \%)$ concentration (data not shown).

\subsection{Catalyst characterization}

After the $650^{\circ} \mathrm{C}$-calcination, XRD analysis of the as prepared $\mathrm{Ag} / \mathrm{ZrO}$ revealed the presence of metallic silver at Ag loading higher than 3.5 at $\%$. Neither silver oxide nor metallic silver were detected at low Ag

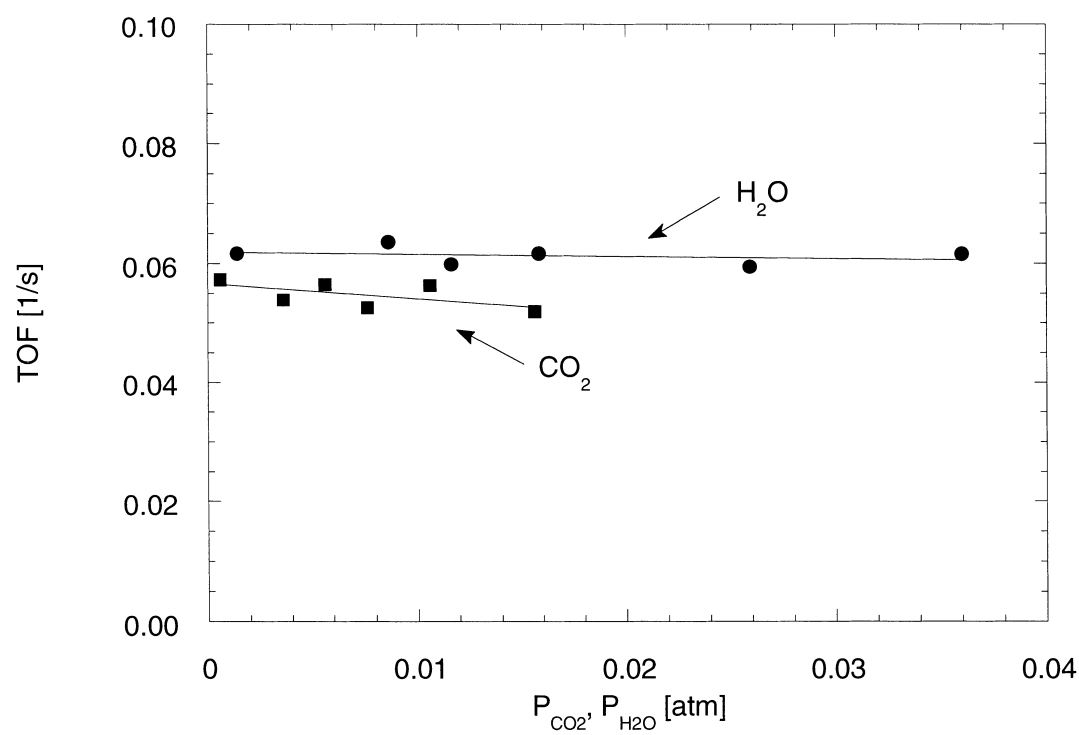

Fig. 5. Effect of $\mathrm{H}_{2} \mathrm{O}$ and $\mathrm{CO}_{2}$ partial pressure on the turnover frequency (TOF) of methane oxidation over 5 at $\% \mathrm{Ag} / \mathrm{ZrO}_{2}\left(500^{\circ} \mathrm{C} ; 1 \% \mathrm{CH}_{4}\right.$, $5 \% \mathrm{O}_{2}$, balance $\mathrm{He} ; 0.012 \mathrm{~g} \mathrm{~s} / \mathrm{cm}^{3}(\mathrm{STP})$ ). 


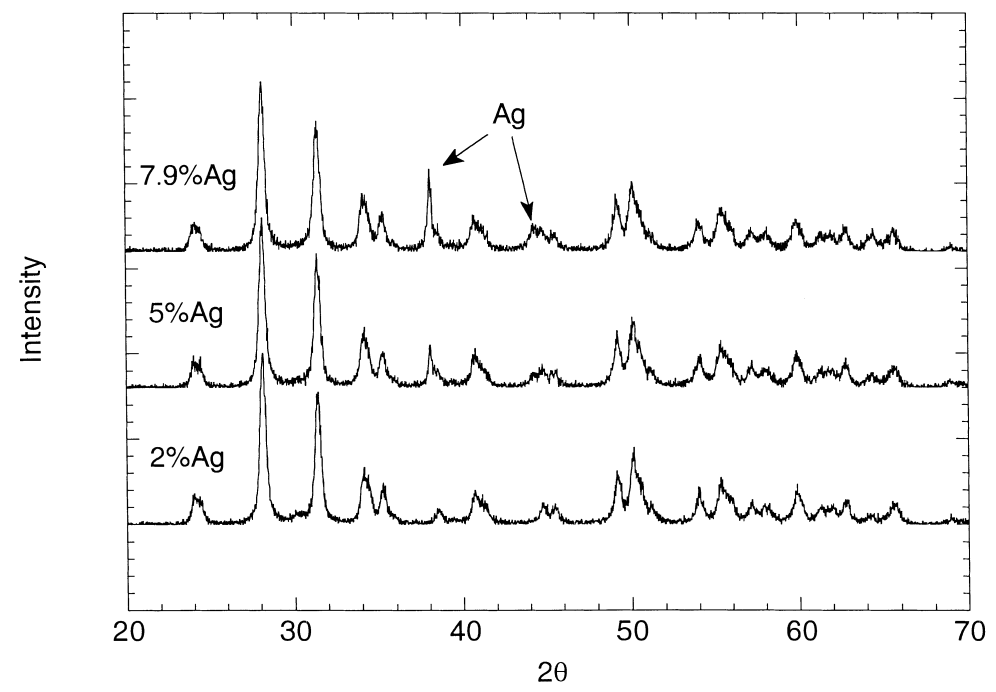

Fig. 6. $\mathrm{XRD}$ analysis of several $\mathrm{Ag} / \mathrm{ZrO}_{2}$ catalysts.

loading $(<3.5$ at\%). XRD patterns of three Ag-containing catalysts are shown in Fig. 6 . The zirconia support was a mixture of monoclinic and tetragonal phases. The crystallite size, determined by the Scherrer equation from the XRD peak broadening, is shown in Table 1. The XRD-determined crystallite size was 3-4 times higher than the crystallite size measured by chemisorption for samples with Ag loading higher than 3.5 at\%. Non-uniform particle size distribution can be a reason for such behavior. When the sample consists of a large number of small crystallites and a small number of large crystallites, the width of the diffraction peak is determined mostly by the sharp peak of the larger crystallites.

To investigate the silver distribution, the catalyst microstructure was analyzed by STEM/EDX. Elemental mappings of several $\mathrm{Ag}$ containing catalysts are shown in Fig. 7. Bright areas in Fig. 7 show elemental distribution of oxygen, zirconia and silver. Detailed characterization of the 1 and 2 at $\% \mathrm{Ag} / \mathrm{ZrO}_{2}$ catalysts showed uniform distribution of silver on the zirconia matrix. The elemental mapping of the 2 at $\% \mathrm{Ag} / \mathrm{ZrO}_{2}$ sample is shown in Fig. 7(a). At higher Ag loading $(>4$ at\%) Ag-rich and Zr-rich areas were identified (Fig. 7(b) and (c)). Ag is uniformly distributed in the zirconia in the zirconia-rich regions as shown in Fig. 7(b) and (d) for the 5 and 10 at $\% \mathrm{Ag} / \mathrm{ZrO}_{2}$, respectively. However, occasionally, isolated $\mathrm{Ag}$ particles covered by zirconia were identified (Fig. 7(c)).
We believe that large Ag particles at high Ag loading give rise to the observed XRD diffraction peaks, so that the crystallite size determined from XRD is overestimated. This explains why the size based on chemisorption (Table 1) data was smaller. Large silver particles covered by zirconia probably do not contribute to the measured oxygen uptake during chemisorption measurements. Moreover, large Ag particles are not likely to contribute to the catalyst activity, since they appear to be covered by zirconia particles (Fig. 7(c)).

The finely dispersed Ag nanoparticles in the 1 and 2 at $\% \mathrm{Ag} / \mathrm{ZrO}_{2}$ samples could not be identified by XRD. HRTEM equipped with an EDX probe was used to detect the size of these dispersed $\mathrm{Ag}$ particles. Fig. 8(a) and (b) show HRTEM micrographs of the 1 and 5 at $\% \mathrm{Ag} / \mathrm{ZrO}_{2}$, respectively. Only particles smaller than $7 \mathrm{~nm}$ were found in the 1 and 2 at $\%$ $\mathrm{Ag} / \mathrm{ZrO}{ }_{2}$ catalysts. The 5 at $\% \mathrm{Ag} / \mathrm{ZrO}_{2}$ catalyst, in addition to a large fraction of small particles $(5 \mathrm{~nm})$, contains silver present as larger $(>7 \mathrm{~nm})$ particles. This causes the surface and volume averaged particle size to be greater than the arithmetic mean. The calculated average particle size is shown in Table 1. The particle size determined from chemisorption is close to that determined by HRTEM.

Detailed analysis of the HRTEM micrographs revealed that at low loading (1 at\%) small Ag particles are mainly monocrystalline, or polycrystalline with a 
a
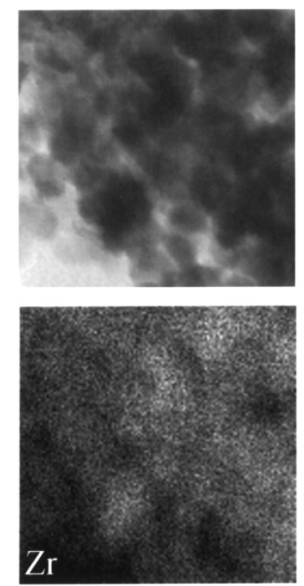

c
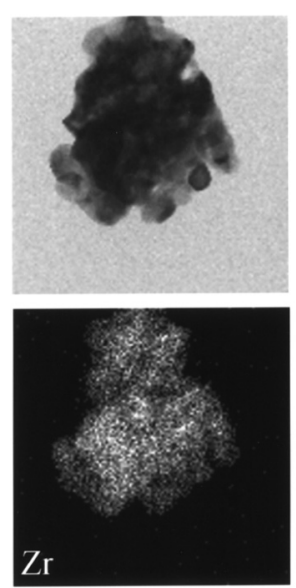
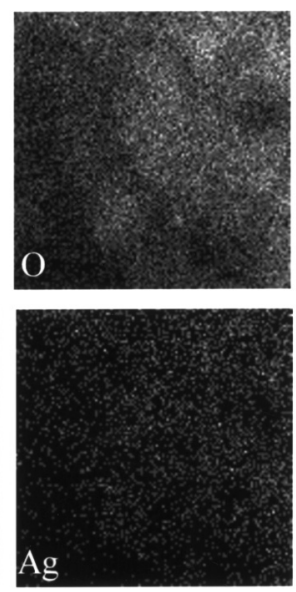

$\mathrm{Ag}$
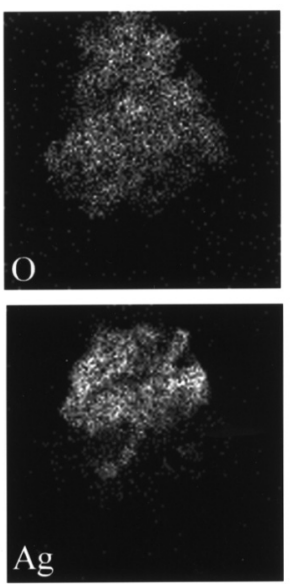

b
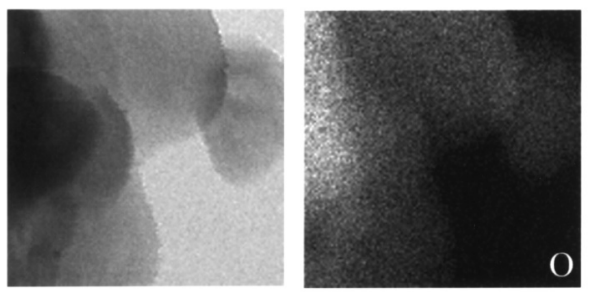

$20 \mathrm{~nm}$
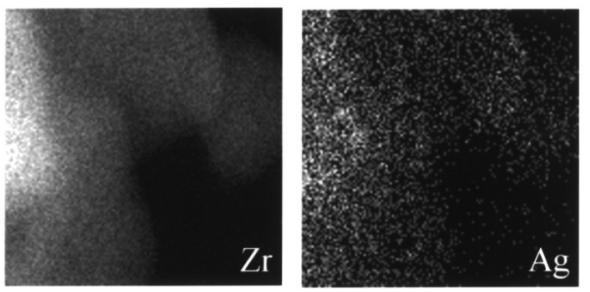

d
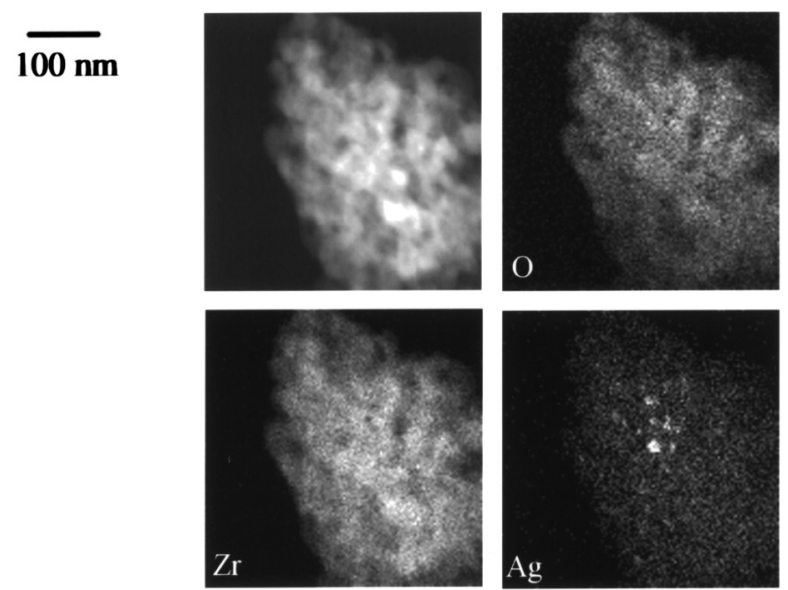

Fig. 7. STEM/EDX elemental mapping of: (a) 2 at $\% \mathrm{Ag} / \mathrm{ZrO}{ }_{2}$, (b) 5 at $\% \mathrm{Ag} / \mathrm{ZrO}_{2}$ (zirconia-rich region), (c) 5 at $\% \mathrm{Ag} / \mathrm{ZrO}{ }_{2}(\mathrm{Ag}$-rich region), (d) 10 at $\% \mathrm{Ag} / \mathrm{ZrO}_{2}$.

small number of defects (Fig. 8(a)). At higher Ag loading (5 at\%), the larger $\mathrm{Ag}$ particles are clearly polycrystalline (Fig. 8(b)), containing a large number of grain boundaries and defects. The Ag particles seen in $5 \mathrm{at} \% \mathrm{Ag} / \mathrm{ZrO}_{2}$ are polycrystalline and probably have different crystal plane distribution than the small particles in 1 at $\% \mathrm{Ag} / \mathrm{ZrO}_{2}$ as well as different oxygen adsorption properties. It is known that oxygen adsorption on silver is structurally sensitive, e.g. the $\left(\begin{array}{lll}1 & 1 & 1\end{array}\right)$ faces are relatively inert compared to the $\left(\begin{array}{lll}1 & 1 & 0\end{array}\right)$ and (1 $\left.\begin{array}{ll}0 & 0\end{array}\right)$ faces [23]. It is also known that the ethylene epoxidation rate over $\mathrm{Ag} / \mathrm{Al}_{2} \mathrm{O}_{3}$ catalysts increases when the $\mathrm{Ag}$ particle size increases above $50 \mathrm{~nm}$, and this can be related to the structure of $\mathrm{Ag}$ particles [39]. Structural differences between low- and highAg-containing samples may explain their different catalytic behavior in the complete oxidation of methane. The second possibility for a large difference in activity may be the difference in the oxidation state at low and high Ag loading. When oxygen is present, it is possible that smaller $\mathrm{Ag}$ crystallites are oxidized to Ag oxide, resulting in lower activity.

Ag ion-exchanged ZSM-5 catalysts contain a large fraction of $\mathrm{Ag}$ in highly dispersed state (isolated ions). These materials show poor activity for the oxidation of methane (Fig. 1). XRD analysis of $\mathrm{Ag}$ exchanged 


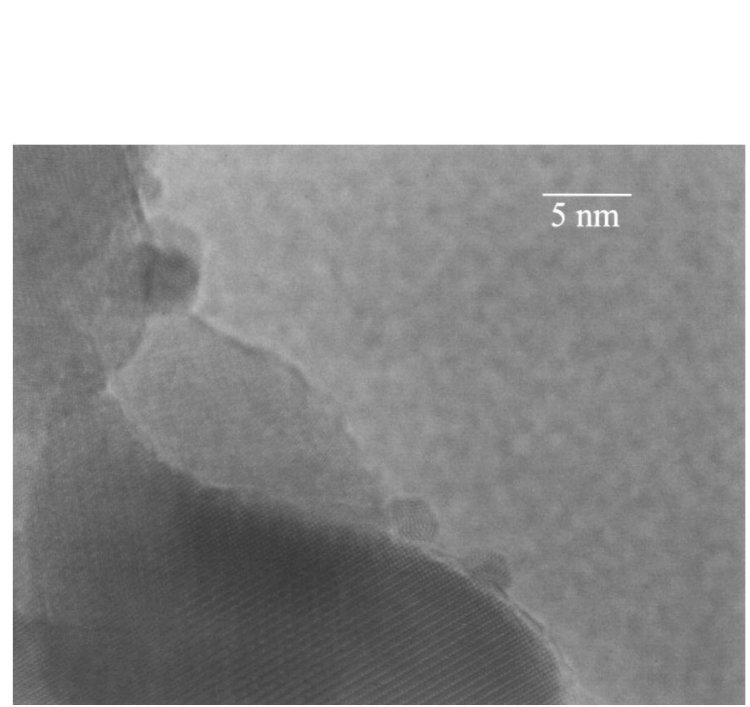

a

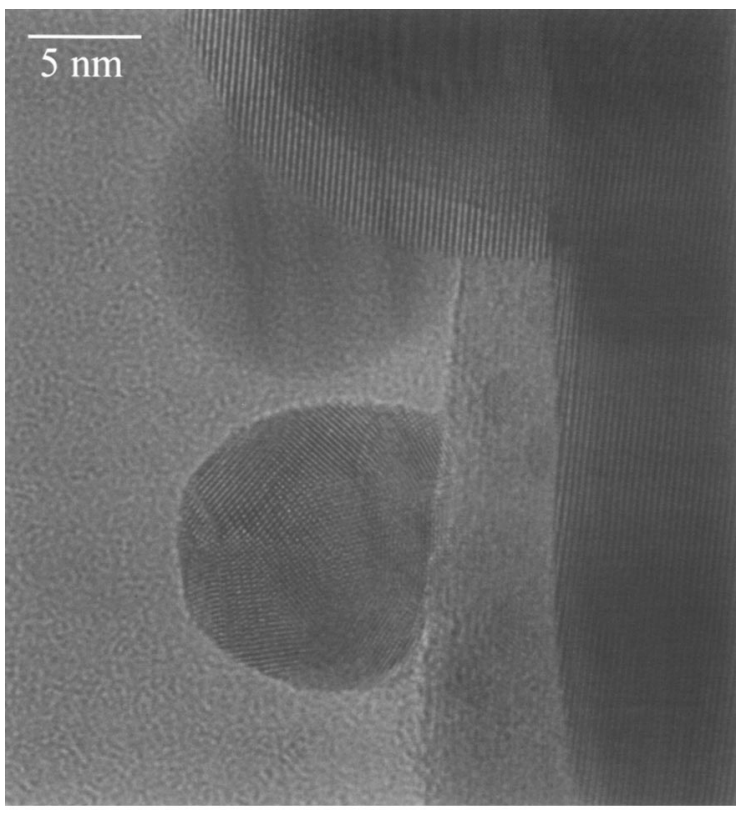

b

Fig. 8. HRTEM of 1 at $\% \mathrm{Ag} / \mathrm{ZrO}_{2}$, (b) 5 at $\% \mathrm{Ag} / \mathrm{ZrO}_{2}$.

ZSM-5 materials did not identify any distinct $\mathrm{Ag} / \mathrm{Ag}$ oxide reflections [44]. STEM/EDX elemental mapping of $\mathrm{Ag}(16)$-ZSM-5 showed uniform distribution of $\mathrm{Ag}$ in the zeolite matrix [44]. At higher Ag loading, however, as in the $\operatorname{Ag}(83)-Z S M-5$ material, some agglomeration of $\mathrm{Ag}$ to larger nanoparticles was observed on the surface of the zeolite by HRTEM [44]. The presence of these Ag particles appears to be the reason for the higher methane oxidation activity of the $\operatorname{Ag}(83)-Z S M-5$ catalyst (Fig. 1). To check the above hypothesis we used UV-Vis spectrometry and XPS to identify potentially different Ag states at different $\mathrm{Ag}$ loading.

Fig. 9 shows UV-Vis diffuse reflectance spectra of various as prepared $\mathrm{Ag} / \mathrm{ZrO}_{2}$ materials recorded at room temperature on samples exposed to ambient conditions. The DR spectrum of the $\mathrm{ZrO}_{2}$ support is also shown for comparison. $\mathrm{ZrO}_{2}$ has absorption bands in the $200-300 \mathrm{~nm}$ range. Isolated $\mathrm{Ag}$ ions have absorption bands at 190 and $220 \mathrm{~nm}$ [45-47]. Their presence in the $\mathrm{Ag} / \mathrm{ZrO}_{2}$ catalysts could not be clearly identified due to the strong absorption of $\mathrm{ZrO}_{2}$. For the 1 at $\% \mathrm{Ag} / \mathrm{ZrO}_{2}$ material, increased absorption intensity compared to the zirconia is observed at $\sim 290$ and $\sim 400 \mathrm{~nm}$. The presence of the $\mathrm{Ag}_{\mathrm{n}}^{\delta+}$ clusters gives rise to absorption bands at 280 and $380 \mathrm{~nm}[38,45,46]$. These bands can be tentatively assigned to the small oxidized Ag clusters. As the Ag loading increases, the intensity at $290 \mathrm{~nm}$ increases, accompanied by baseline increase at 300-800 $\mathrm{nm}$. The absorption band of metallic $\mathrm{Ag}_{\mathrm{n}}$ clusters and aggregates at $400-450 \mathrm{~nm}$ $[38,45]$ was absent from the spectra of the as prepared materials. It is known that bulk $\operatorname{Ag}_{2} \mathrm{O}$ cannot be detected by UV-Vis DR spectrometry [45]. However, a higher oxidation state seems possible in view of the absence of clear metallic absorption bands. In addition, the absorption band at $315 \mathrm{~nm}$, usually attributed to the presence of the massive Ag particles (silver film with thickness of $5000 \mathrm{~nm}$ ), is absent from the spectra [45]. Thus, no presence of silver metal is detected in the as prepared materials. However, XRD analysis identified metallic Ag at higher Ag content (Fig. 6). It is known that adsorption of oxygen on $\mathrm{Ag}$ surfaces leads to the formation of surface oxide $[25,32]$. Therefore, these results suggest that oxygen-covered (possibly oxide covered) metallic Ag is present in the as prepared materials.

The UV-Vis DR spectra of Ag ion-exchanged ZSM-5 have different features (Fig. 10). The spectra shown in Fig. 10 indicate that Ag-exchanged catalysts 
Lj. Kundakovic, M. Flytzani-Stephanopoulos/Applied Catalysis A: General 183 (1999) 35-51

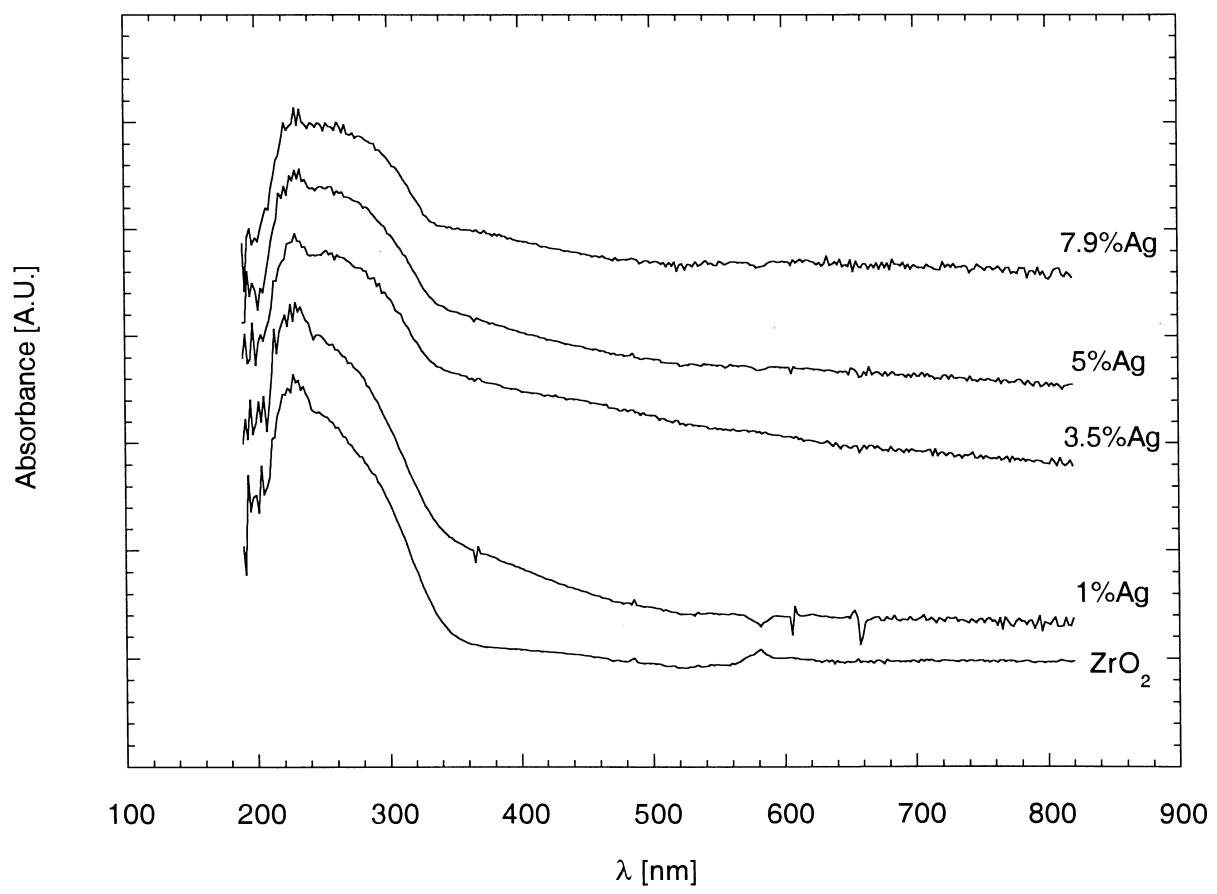

Fig. 9. UV-Vis DR spectra of various as prepared $\mathrm{Ag} / \mathrm{ZrO}_{2}$ catalysts at $25^{\circ} \mathrm{C}$.

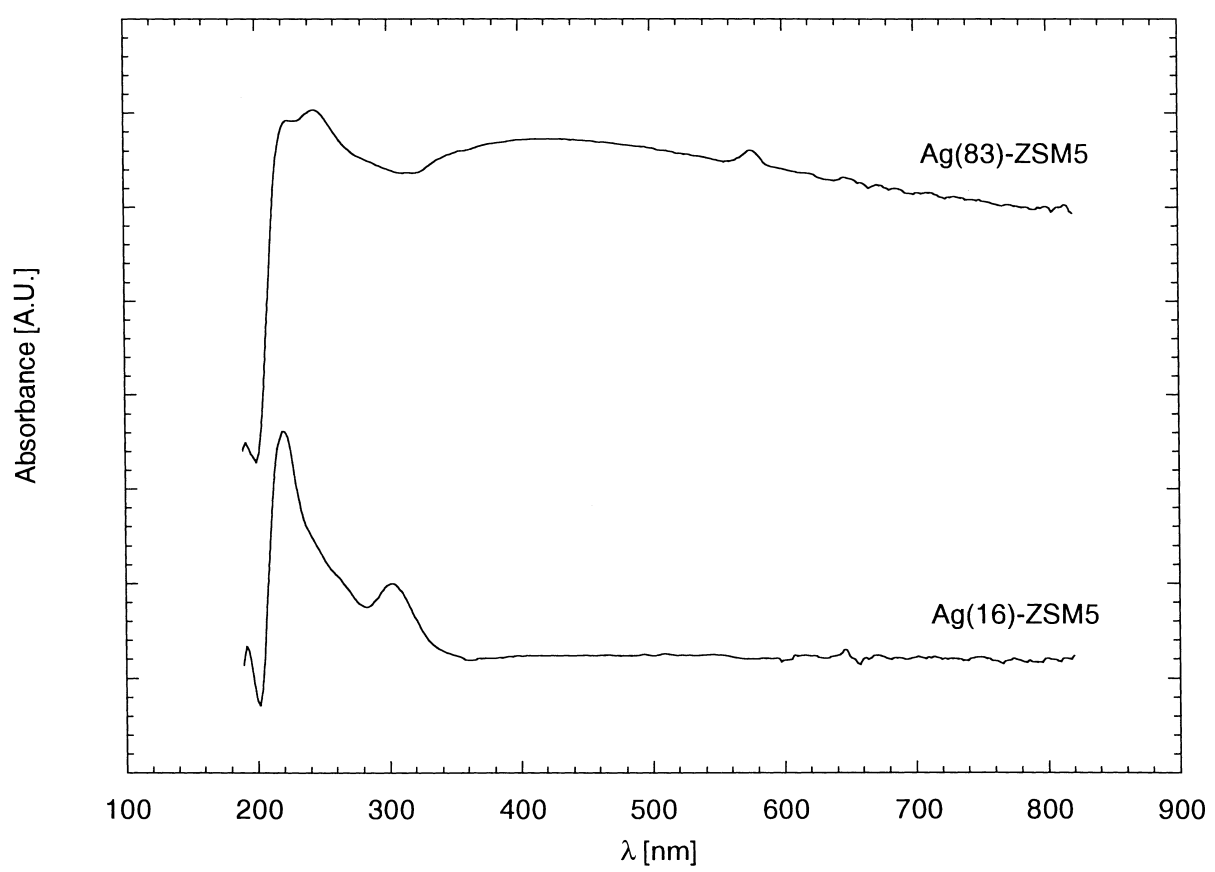

Fig. 10. UV-Vis DR spectra of $\mathrm{Ag}(16)-Z \mathrm{SM}-5$ and $\mathrm{Ag}(83)-Z \mathrm{SM}-5$ catalysts. 
contain multiple Ag species. At low Ag exchange level, absorption bands at 220 and $300 \mathrm{~nm}$ and a shoulder at $260 \mathrm{~nm}$ were detected. At high $\mathrm{Ag}$ exchange level, in addition to the absorption band at $220 \mathrm{~nm}$, a strong band at $245 \mathrm{~nm}$ and a broad band at $450 \mathrm{~nm}$ are observed. The band at $220 \mathrm{~nm}$ is usually attributed to isolated $\mathrm{Ag}^{+}$ions $[45,47,48]$. The absorption bands at 260, 340 and $400 \mathrm{~nm}$ are assigned to $\mathrm{Ag}_{\mathrm{n}}^{\mathrm{\delta}}$ clusters [45,51-53] observed in Ag-exchanged zeolites and inert gas matrices. The absorption band at $300 \mathrm{~nm}$ observed in the spectra of Ag(16)-ZSM-5 may be due to the presence of reduced Ag clusters [49,50] or silver film-like structure $[45,46]$. The absorption band at the $450 \mathrm{~nm}$ can be associated with the small metallic Ag particles located inside the zeolite cages or with the larger Ag particles located on the outside surface $[45,46,52]$. This band disappears after exposure to oxygen at $300^{\circ} \mathrm{C}$ [44], confirming the presence of reduced $\mathrm{Ag}$ species.

It is evident that Ag ion-exchanged ZSM-5 materials contain isolated $\mathrm{Ag}^{+}$ions, isolated $\mathrm{Ag}^{0}$ atoms at low Ag loading, and small metallic Ag particles at higher Ag loading. The latter are the most active for the complete oxidation of methane, while the activity of the isolated $\mathrm{Ag}$ ions is fairly poor (Fig. 1).

The presence of the isolated $\mathrm{Ag}^{+}$ions in the $\mathrm{Ag} /$ $\mathrm{ZrO}_{2}$ catalysts could not be confirmed by UV-Vis spectrometry due to the strong absorption of the support, in the 200-300 nm range as mentioned above. The absorption bands at 280 and $390 \mathrm{~nm}$ could be attributed to the oxidized $\mathrm{Ag}_{\mathrm{n}}^{\delta+}$ clusters. In agreement with the XRD data (Fig. 6) the active state for methane oxidation appears to be the oxygen covered Ag metal surface.

The presence of oxidic Ag species in the $\mathrm{Ag} / \mathrm{ZrO}{ }_{2}$ materials was confirmed by XPS. Fig. 11 shows MNN Auger electron spectra of the 2 and 3.5 at $\% \mathrm{Ag} / \mathrm{ZrO}{ }_{2}$ catalysts. For both samples, the Auger $\mathrm{M}_{4} \mathrm{~N}_{45} \mathrm{~N}_{45}$ peak was found between the kinetic energies of $\mathrm{Ag}^{0}$ (358.1 eV) and $\mathrm{Ag}^{+}(356.6 \mathrm{eV})$. The calculated Auger parameter was 725.1 and $725.5 \mathrm{eV}$ for the $2 \% \mathrm{Ag}$ and $3.5 \% \mathrm{Ag} / \mathrm{ZrO}_{2}$, respectively. On the basis of the values of the Auger parameter reported in the literature, namely $725.8-726.3 \mathrm{eV}$ for metallic $\mathrm{Ag}$ and $724.5 \mathrm{eV}$ for $\mathrm{Ag}_{2} \mathrm{O}$ [54], the surface of the Ag particles appears to be partially oxidized.

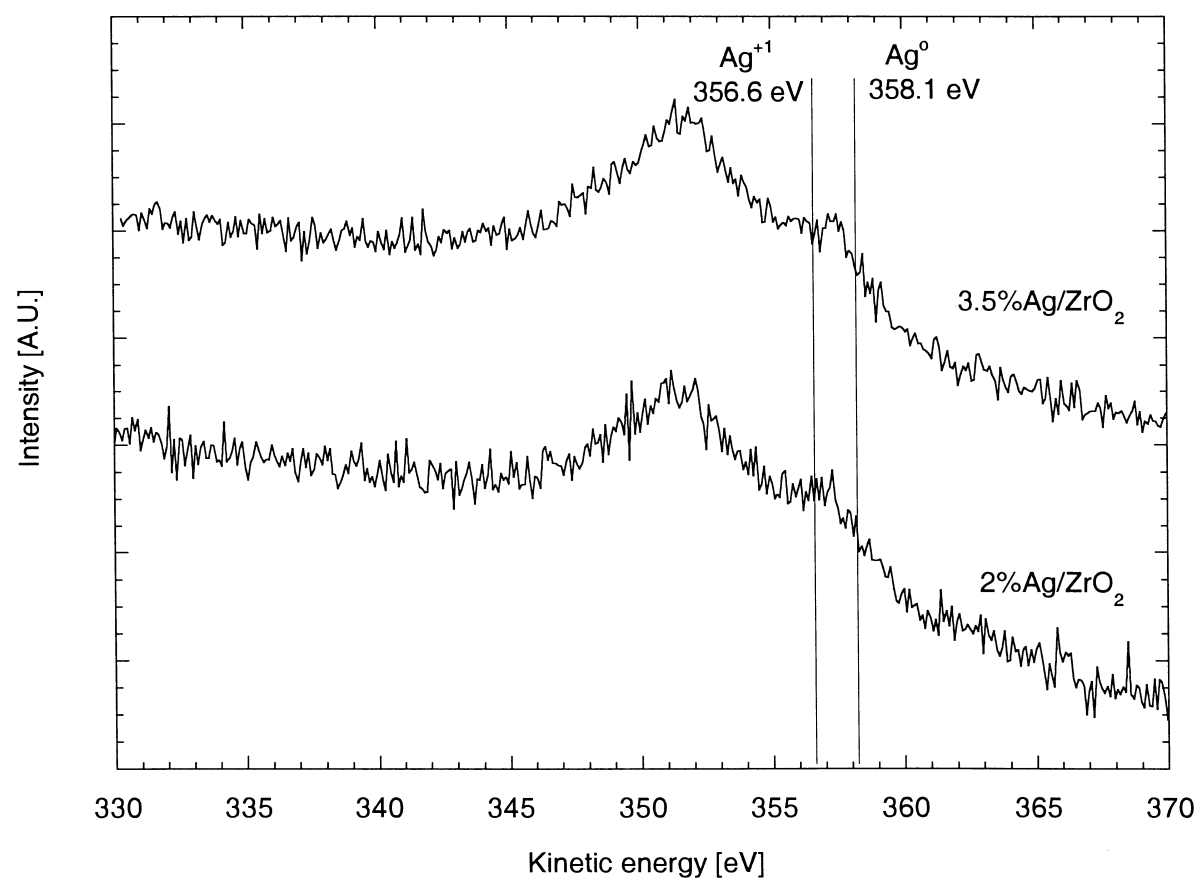

Fig. 11. Auger $\mathrm{MNN}$ spectra of the $\mathrm{Ag} / \mathrm{ZrO}_{2}$ catalysts. 


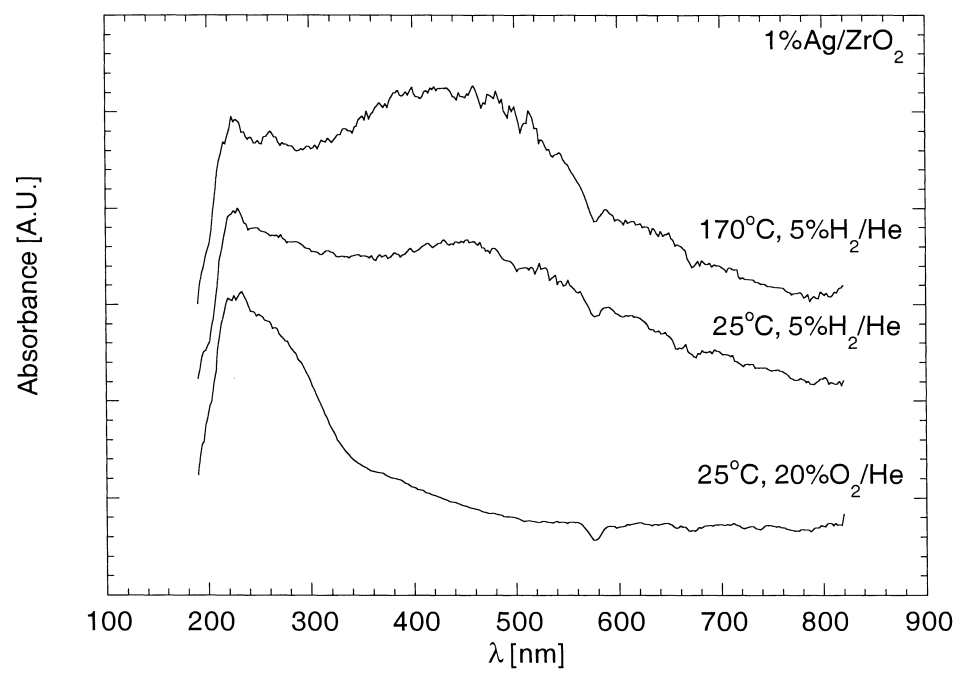

Fig. 12. UV-Vis DR spectra of $1 \mathrm{at} \% \mathrm{Ag} / \mathrm{ZrO}_{2}$ under oxidizing and reducing conditions.

The presence of the oxidic Ag species was also confirmed by in-situ reduction experiments in the UVVis reaction chamber at different temperatures. Oxygen present on the surface of the $\mathrm{Ag} / \mathrm{ZrO}_{2}$ materials can be reduced by $\mathrm{H}_{2}$ even at room temperature as observed by the presence of the band at $450 \mathrm{~nm}$ in the UV-Vis DR spectra of 1 at $\% \mathrm{Ag} / \mathrm{ZrO}_{2}$ (Fig. 12). As the reduction temperature increases to $170^{\circ} \mathrm{C}$ the intensity of the absorption band at $450 \mathrm{~nm}$ increases. Similar behavior is observed during reduction of
5 at\% $\mathrm{Ag} / \mathrm{ZrO}$. Reduction starts as low as room temperature and a large absorption band at $450 \mathrm{~nm}$ is seen, consistent with the presence of small $\mathrm{Ag}$ metal particles [45]. When the samples were heated in the $20 \% \mathrm{O}_{2} / \mathrm{He}$ mixture, the observed DR spectra were identical to those measured for the fresh materials. Furthermore, the DR spectra recorded under reaction conditions $\left(1 \% \mathrm{CH}_{4}, 8 \% \mathrm{O}_{2}\right)$ were identical to the ones collected on the as prepared catalysts up to $580^{\circ} \mathrm{C}$ (Fig. 13).

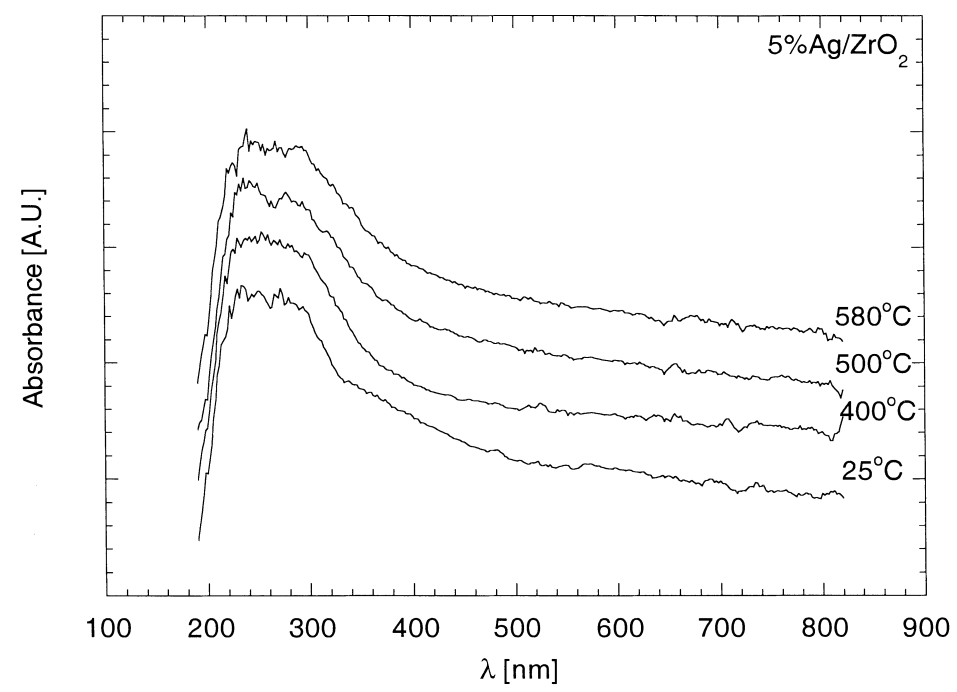

Fig. 13. UV-Vis DR spectra of 5 at $\% \mathrm{Ag} / \mathrm{ZrO}_{2}$ under reaction conditions, $1 \% \mathrm{CH}_{4}, 8 \% \mathrm{O}_{2}$. 


\section{Discussion}

$\mathrm{Ag} / \mathrm{ZrO}_{2}$ materials are active catalysts for the complete oxidation of methane at temperatures higher than $300^{\circ} \mathrm{C}$. The activity is strongly influenced by the state of silver. Highly dispersed $\mathrm{Ag}$ as in low Ag-containing Ag-ZSM-5 is much less active than the Ag nanoparticles found in highly loaded Ag-ZSM-5 catalysts and low-content (1-2 at\%) $\mathrm{Ag} / \mathrm{ZrO}_{2}$ catalysts. The turnover frequency increases as the $\mathrm{Ag}$ loading on zirconia increases, while the apparent activation energy remains unchanged. The main change in TOF occurs when the Ag particle size is below $10 \mathrm{~nm}$ as determined from the oxygen chemisorption experiments (Fig. 2). The activity of the catalysts with Ag particle size above $\sim 10 \mathrm{~nm}$ is slowly increasing. The particle size of $\sim 10 \mathrm{~nm}$ corresponds to Ag loading of about 5 at\% for the $\mathrm{ZrO}_{2}$ support used in this study. At this loading, metallic Ag reflections were identified by XRD (Fig. 6) indicating that the larger silver particles present at this loading but not at lower Ag content are more active for the complete oxidation of methane.

The state of Ag depends on Ag loading. At low Ag content in $\mathrm{Ag} / \mathrm{ZrO}_{2}$ catalysts, silver is present in dispersed form with particle size $\sim 5 \mathrm{~nm}$ as determined from the chemisorption experiments. These particles could not be identified by XRD. It is possible that some of the Ag in the low Ag loading materials is in the form of isolated ions, which have low activity for the oxidation of methane, as is shown by the poor activity of the $\operatorname{Ag}(16)-Z S M-5$ catalyst (Fig. 1). The presence of isolated $\mathrm{Ag}^{+}$ions is clearly identified in Ag-exchanged ZSM-5 materials by UV-Vis spectrometry (absorption band at $220 \mathrm{~nm}$ in Fig. 10). Isolated $\mathrm{Ag}$ ions could not be identified clearly in $\mathrm{Ag} / \mathrm{ZrO}{ }_{2}$ samples due to the strong absorption of the zirconia support. In the $\operatorname{Ag}(83)-Z S M-5$ catalyst, in addition to isolated ions, small metallic $\mathrm{Ag}$ particles are identified by UV-Vis spectroscopy. These are more active than the isolated $\mathrm{Ag}^{+}$ions. The activity of the $\mathrm{Ag}(83)-$ $\mathrm{ZSM}-5$ is similar to the 1 at $\% \mathrm{Ag} / \mathrm{ZrO}_{2}$ materials, which contains small metallic Ag particles $(\sim 5 \mathrm{~nm})$. As the particle size increases to about $10 \mathrm{~nm}$ as determined by chemisorption on $\mathrm{Ag} / \mathrm{ZrO}{ }_{2}$ catalysts, the turnover rate for methane oxidation increases and then it levels off.

A similar behavior of Pd and Pt-containing materials for the complete oxidation of methane has been reported in the literature. Several authors reported that the turnover rate of methane oxidation increases as the $\mathrm{Pd}$ particle size increases [10,11,13]. Otto [17] reported that highly dispersed $\mathrm{Pt}$ on alumina, present at low Pt loading $(<1.4 \mathrm{wt} \% \mathrm{Pt})$ has low activity compared to the larger particles of $\mathrm{Pt}$, present at higher Pt loading (>1.4 wt\% Pt). Some studies of Ag-containing catalysts for the SCR of NO indicate that the activity of $\mathrm{Ag}$ for the hydrocarbon oxidation shows the same trend. Haneda et al. [35] reported that the propene oxidation in SCR of NO is enhanced at lower temperature as the $\mathrm{Ag}$ loading increases (from 1 to $15 \mathrm{wt} \%$ ) for $\mathrm{Ag}$ supported on $\mathrm{TiO}_{2} / \mathrm{ZrO}_{2}$. These authors reported an $\mathrm{Ag}$ particle size in the range of $50-100 \mathrm{~nm}$ (at $5 \mathrm{wt} \% \mathrm{Ag} / \mathrm{TiO}_{2}-\mathrm{ZrO}_{2}$ ), and suggested that partially oxidized $\mathrm{Ag}$ is the active phase [35]. Similarly, Bethke and Kung [38] reported higher propene oxidation rate in the SCR over a $6 \mathrm{wt} \%$ $\mathrm{Ag} / \mathrm{Al}_{2} \mathrm{O}_{2}$ compared to $2 \mathrm{wt} \% \mathrm{Ag} / \mathrm{Al}_{2} \mathrm{O}_{2}$. These authors attributed the observed behavior to the fact that the oxidation state of $\mathrm{Ag}$ was different on the two catalysts under reaction conditions. In the low Agloaded sample $(2 \mathrm{wt} \% \mathrm{Ag})$ the $\mathrm{Ag}^{+}$oxidation state was proposed, while in the $6 \mathrm{wt} \% \mathrm{Ag}$-sample metallic $\mathrm{Ag}$ was observed [38]. Similarly, Hoost et al. [55] concluded that the oxidized rather than reduced form of $\mathrm{Ag}$ is the active phase for SCR of NO for $\mathrm{Ag} /$ alumina catalysts. In the present study isolated $\mathrm{Ag}^{+}$ ions could not be unambiguously identified by UVVis spectrometry. However, distinct Ag metal particles were observed by HRTEM even at low Ag loading (Fig. 8(a)). In addition, the XPS data indicate that the oxidation state of $\mathrm{Ag}$ at the surface is +1 on both highand low-Ag containing samples (Fig. 11).

On the basis of the above findings, we propose that the active surface for the methane oxidation reaction is the oxygen-covered, or possibly the oxide-covered surface of metallic $\mathrm{Ag}$ particles. The $\mathrm{Ag}^{+}$oxidation state in $\mathrm{Ag} / \mathrm{ZrO}{ }_{2}$ materials was identified in this study by XPS (Fig. 11) and UV-Vis spectrometry (Figs. 9 and 12). The oxygen or surface oxide present on the catalysts is highly reducible (reduction readily occurs at room temperature in $5 \% \mathrm{H}_{2} / \mathrm{He}$ ). Bulk $\mathrm{Ag}_{2} \mathrm{O}$ is known to decompose at $\sim 315^{\circ} \mathrm{C}$ in air [56]. Room temperature reduction of $\mathrm{Ag}_{2} \mathrm{O}$ for $\mathrm{Ag}$ supported on alumina was observed by Bethke and Kung [38]. The same authors [38] reported that the oxidized form of $\mathrm{Ag}$ was more stable in the $2 \mathrm{wt} \% \mathrm{Ag} /$ alumina than in 
the $6 \mathrm{wt} \% \mathrm{Ag}$ /alumina material. With respect to our XRD results and the low temperature decomposition of $\mathrm{Ag}_{2} \mathrm{O}$, metallic $\mathrm{Ag}$ covered with oxygen appears to be the active catalyst state. Bulk $\mathrm{Ag}_{2} \mathrm{O}$ is not thermodynamically stable at high temperatures, so that $\mathrm{Ag}$ metal covered by a stable surface oxygen species appears to be the active phase at reaction temperatures exceeding $400^{\circ} \mathrm{C}$.

Studies of oxygen adsorption on Ag surfaces indicate that more than one form of adsorbed oxygen exists $[19,20]$. There is evidence that a molecularly adsorbed oxygen species exist at low temperatures and two types of adsorbed atomic oxygen can occur at higher temperature on the single crystal (1 110$) \mathrm{Ag}$ surfaces [23,24,28,32]. Two types of atomic oxygen species, namely: a chemisorbed surface atomic oxygen and subsurface oxygen, were identified as a result of dissociative oxygen adsorption on a single crystal (1 110$)$ Ag surface [25] and polycrystalline Ag foils $[26,27]$. Chemisorbed surface oxygen recombines and desorbs at $590 \mathrm{~K}[26,27]$. Dissolution of oxygen into the bulk Ag starts at $T>470 \mathrm{~K}$. As a result of oxygen chemisorption at higher temperatures and pressures, stable oxygen species are formed, which do not desorb below $800 \mathrm{~K}\left(520^{\circ} \mathrm{C}\right)$ from the single crystal $\left(\begin{array}{lll}1 & 1 & 0\end{array}\right)$ surface [25]. Similarly, Bukhtiyarov et al. [26,27] showed that these oxygen species are stable up to $800 \mathrm{~K}$ on polycrystalline $\mathrm{Ag}$ foils. The nature of active oxygen species for methane oxidation could not be identified by the methods used in this study. However, XPS and UV-Vis DR results suggest that the active catalyst surface is partially oxidized silver, and that the oxygen species present are highly reducible. Both redox mechanism (reduction of surface oxygen by methane and surface reoxidation by molecular oxygen) and the Langmuir-Hinshelwood mechanism (reaction of adsorbed methane with adsorbed oxygen) are consistent with the observed kinetics.

The low activity of small $\mathrm{Ag}$ crystallites for the complete oxidation of methane may be viewed in terms of oxygen adsorption. Anderson et al. [31], have reported that the heat of oxygen adsorption on small $\mathrm{Ag}$ crystallites $(3.7 \mathrm{~nm})$ is $50 \mathrm{kcal} / \mathrm{mol}$, higher than that on large $(27 \mathrm{~nm}) \mathrm{Ag}$ crystallites. The heat of adsorption on large $\mathrm{Ag}$ crystallites was close to that reported for single crystals $(34-41 \mathrm{kcal} / \mathrm{mol})$. These properties of small Ag crystallites would lead to a stronger $\mathrm{Ag}-\mathrm{O}$ bond and decrease the number of surface sites for methane adsorption under reaction conditions.

In view of our HRTEM data, a slightly different explanation is postulated. The important feature of the small Ag crystallites (Fig. 8(a) and (b)) is that they appear monocrystalline or polycrystalline with a small number of surface defects. On the other hand, larger Ag particles appear to be polycrystalline with a large number of defects and grain boundaries. The $\left(\begin{array}{lll}1 & 1 & 1\end{array}\right)$ crystal face was shown to be the dominant face present in alumina-supported Ag catalysts [57] and powders [58]. However, the $\left(\begin{array}{lll}1 & 1 & 1\end{array}\right)$ face is relatively inert compared to the (1 110$)$ face. In terms of oxygen adsorption, much lower sticking coefficients have been reported for the $\left(\begin{array}{lll}1 & 1 & 1\end{array}\right)$ crystal face of silver $[23,28]$. The small number of surface defects and the low reactivity of the predominant $\left(\begin{array}{lll}1 & 1 & 1\end{array}\right)$ face could explain the low activity of the 1 and 2 at $\% \mathrm{Ag} / \mathrm{ZrO}_{2}$ samples. On the other hand, at higher Ag loading, larger $\mathrm{Ag}$ particles $(>5 \mathrm{~nm})$ are present containing a high number of surface defects, which may explain their higher activity [40]. It is also known that the ethylene epoxidation rate over $\mathrm{Ag} / \mathrm{Al}_{2} \mathrm{O}_{3}$ catalysts increases when the $\mathrm{Ag}$ particle size increases above $50 \mathrm{~nm}$. Tsybulya et al. [39] correlated the proportionately lower number of grain boundaries in these large Ag particles $(>50 \mathrm{~nm})$ with the epoxidation activity. Their result shows the importance of intergrain boundaries of silver particles for the reactivity of $\mathrm{Ag}$. In addition to oxidation state, structural differences between low and high Ag-containing samples may, thus, also contribute to their different catalytic behavior in the complete oxidation of methane.

\section{Summary}

Zirconia-supported Ag catalysts are active for deep oxidation of methane at temperatures higher than $300^{\circ} \mathrm{C}$. The reaction order in methane was found to be 0.77 , and the reaction order in oxygen was 0.37 . The reaction products, carbon dioxide and water, do not influence the rate up to 1.7 and $3.5 \mathrm{~mol} \%$ in the gas, respectively. In this regard, silver catalysts are superior to the $\mathrm{PdO}$ catalysts reported in the literature.

The catalyst activity for the complete oxidation of methane depends on the Ag state and dispersion. The turnover rate increases as the $\mathrm{Ag}$ particle size 
increases up to $10 \mathrm{~nm}$. Further increase in the particle size does not affect the activity. The catalyst structure was studied by XRD, STEM/EDX and HRTEM. At low Ag loading, zirconia-supported catalysts contain $\mathrm{Ag}$ in the form of Ag metal nanoparticles of size around $5 \mathrm{~nm}$, which are not detected by XRD. As the Ag loading increases, larger Ag particles are formed, which give rise to XRD reflections of metallic Ag. The presence of the large Ag particles is confirmed by STEM/EDX and HRTEM measurements. These particles $(>5 \mathrm{~nm})$ are more active for the complete oxidation of methane. The difference in the activity can be related to the different structure and oxygen adsorption properties of small and large silver particles. Small Ag particles are monocrystalline with small number of surface defects. Large Ag particles are polycrystalline, with grain boundaries clearly identified by HRTEM. Formation of large polycrystalline Ag particles is favored at high Ag loading on zirconia support.

The active phase under reaction conditions appears to be a partially oxidized metallic Ag state. A partially oxidized surface is confirmed by both the XPS and UV-Vis measurements. Reduced (metallic) Ag species were not observed under reaction conditions up to $580^{\circ} \mathrm{C}$.

Ag ion-exchanged ZSM-5 catalysts were compared to the $\mathrm{Ag} / \mathrm{ZrO}_{2}$ catalysts. At low Ag loading, AgZSM-5 comprises mainly of isolated $\mathrm{Ag}^{+}$ions, as confirmed by UV-Vis spectroscopy. Isolated $\mathrm{Ag}^{+}$ions have poor activity for the complete methane oxidation. However, at high Ag loading, when Ag nanoparticles are also present, the activity of $\mathrm{Ag}(83)-\mathrm{ZSM}-5$ is similar to that of the 1 at $\% \mathrm{Ag} / \mathrm{ZrO}_{2}$, also containing highly dispersed silver clusters $(<5 \mathrm{~nm}$ in size $)$.

\section{References}

[1] L.D. Pfefferle, W.C. Pfefferle, Catal. Rev.-Sci. Eng. 29 (1987) 219.

[2] T.R. Baldwin, R. Burch, Appl. Catal. 66 (1990) 337.

[3] T.R. Baldwin, R. Burch, Appl. Catal. 66 (1990) 359.

[4] F.H. Ribeiro, M. Chow, R.A. Dalla Betta, J. Catal. 146 (1994) 537.

[5] R.J. Farrauto, M.C. Hobson, T. Kennelly, E.M. Waterman, Appl. Catal. A 81 (1992) 227.

[6] R.J. Farrauto, J.K. Lampert, M.C. Hobson, M. Waterman, Appl. Catal. B 6 (1995) 263.
[7] J.K. Lampert, M.S. Kazi, R.J. Farrauto, Appl. Catal. B 14 (1997) 211.

[8] T. Maillet, C. Solleau, J. Barbier Jr., D. Duprez, Appl. Catal. B 14 (1997) 85.

[9] P.G. Tsyrulnikov, O.N. Kovalenko, L.L. Gogin, T.G. Starostina, A.S. Noskov, A.V. Kalinkin, G.N. Krukova, S.V. Tsybulya, E.N. Kudrya, A.V. Bubnov, Appl. Catal. B 14 (1997) 31.

[10] R.F. Hicks, H. Qi, M.L. Young, R.G. Lee, J. Catal. 122 (1990) 280.

[11] R.F. Hicks, H. Qi, M.L. Young, R.G. Lee, J. Catal. 122 (1990) 295.

[12] S.H. Oh, P.J. Mitchell, R.M. Siewert, J. Catal. 132 (1991) 287.

[13] K. Fujimoto, F.H. Ribeiro, A.T. Bell, E. Iglesia, Symposium on Heterogeneous Hydrocarbon Oxidation, Div. Petrol. Chem., 211th National Meeting, American Chemical Society, New Orleans, LA, March, 1996, p. 110.

[14] K. Fujimoto, F.H. Ribeiro, E. Iglesia, M. Avalos-Borja, Symposium on Catalytic Combustion, Div. Petrol. Chem., 213th National Meeting, American Chemical Society, San Francisco, CA, April, 1997, p. 190.

[15] Y. Nishizaka, M. Misono, Chem. Lett. 1295 (1993).

[16] Y. Nishizaka, M. Misono, Chem. Lett. 2237 (1994).

[17] K. Otto, Langmuir 5 (1989) 1364.

[18] P.A. Kilty, W.M.H. Sachtler, Catal. Rev.-Sci. Eng. 10 (1974) 1.

[19] X.E. Verykios, F.P. Stein, R.W. Coughlin, Catal. Rev.-Sci. Eng. 22 (1980) 197.

[20] W.M.H. Sachtler, C. Backx, R.A. van Santen, Catal. Rev.-Sci. Eng. 23 (1981) 127.

[21] R.A. van Santen, H.P.C.E. Kuipers, Adv. Catal. 35 (1987) 265.

[22] R.I. Masel, Principles of Adsorption and Reaction on Solid Surfaces, Wiley, New York, 1996, p. 117.

[23] H.A. Engelhardt, D. Menzel, Surf. Sci. 57 (1976) 591.

[24] K.C. Prince, A.M. Bradshaw, Surf. Sci. 126 (1983) 49.

[25] J. Pawela-Crew, R.J. Madix, J. Catal. 153 (1995) 158.

[26] V.I. Bukhtiyarov, A.I. Boronin, V.I. Savchenko, J. Catal. 150 (1994) 262.

[27] V.I. Bukhtiyarov, A.I. Boronin, V.I. Savchenko, J. Catal. 150 (1994) 268

[28] C. Benndorf, M. Frank, F. Thieme, Surf. Sci. 128 (1983) 424.

[29] J.K. Plischke, M.A. Vannice, Appl. Catal. 42 (1988) 255.

[30] S.R. Seyedmonir, D.E. Strohmayer, G.L. Geoffroy, M.A. Vannice, J. Catal. 87 (1984) 424.

[31] K.L. Anderson, J.K. Plischke, M.A. Vannice, J. Catal. 128 (1991) 148

[32] C. Backx, C.P.M. De Groot, P. Biloen, W.M.H. Sachtler, Surf. Sci. 128 (1983) 81.

[33] K. Fujimoto, F.H. Ribeiro, M. Avalos-Borja, E. Iglesia, J. Catal. 179 (1998) 431.

[34] Z. Li, M. Flytzani-Stephanopoulos, Appl. Catal. A 165 (1997) 15.

[35] M. Haneda, Y. Kintaichi, M. Inaba, H. Hamada, Bull. Chem. Soc. Jpn. 70 (1997) 499.

[36] T. Miyadera, Appl. Catal. B 2 (1993) 199.

[37] T. Miyadera, K. Yoshida, Chem. Lett. 1483 (1993). 
[38] K.A. Bethke, H.H. Kung, J. Catal. 172(1) (1997) 93.

[39] S.V. Tsybulya, G.N. Kryukova, S.N. Goncharova, A.N. Shmakov, B.S. Bal'zhinimaev, J. Catal. 154 (1995) 194.

[40] D.A. Bulushev, A. Paukshtis, Y.N. Nogin, S. Bal'zhinemaev, Appl. Catal. A 123 (1995) 301.

[41] W.W. Smeltzer, E.L. Tollefson, A. Cambron, Can. J. Chem. 34 (1956).

[42] X. Li, A. Vannice, J. Catal. 151 (1995) 87.

[43] R.J. Matyi, L.H. Schwartz, J.B. Butt, Cat. Rev.-Sci. Eng. 29(1) (1987) 41.

[44] Z. Li, Ph.D. Thesis, Tufts University, 1998.

[45] A.N. Pestryakov, A.A. Davydov, L.N. Kurina, Russ. J. Phys. Chem. 60(8) (1986) 1251.

[46] A.N. Pestryakov, A.A. Davydov, Appl. Catal. A 120 (1994) 7.

[47] M. Matsuoka, E. Matsuda, K. Tsuji, H. Yamashita, M. Anpo, Chem. Lett. 375 (1995).

[48] J. Texter, J.J. Hastrelter, J.L. Hall, J. Phys. Chem. 87(23) (1983) 4691.

[49] N.E. Bogdanichikova, M.N. Dulin, A.V. Toktarev, G.B.
Shevnina, V.N. Kolomichuk, V.I. Zaikovski, V.P. Petranovski, Stud. Surf. Sci. Catal. 84 (1994) 1067.

[50] B.G. Ershov, E. Janata, A. Henglein, J. Phys. Chem. 97 (1993) 339.

[51] S.A. Mitchell, A. Kenney-Wallace, G.A. Ozin, J. Am. Chem. Soc. 103 (1981) 6030.

[52] G.A. Ozin, F. Hugues, S.M. Matter, D.F. McIntosh, J. Phys. Chem. 87 (1983) 3445.

[53] G.A. Ozin, F. Hugues, J. Phys. Chem. 87 (1983) 94.

[54] D. Brigs, M.P. Seah (Eds.), Practical Surface Analysis by Auger and X-ray Photoelectron Spectroscopy, Wiley, New York, 1983.

[55] T.E. Hoost, R.J. Kudla, K.M. Collins, M.S. Chattha, Appl. Catal. B 13 (1997) 59.

[56] P.G. Dickens, R. Heckingbottom, J.W. Linnett, Trans. Faraday Soc. 65 (1969) 2235.

[57] M. Dean, M. Bowker, Appl. Surf. Sci. 35 (1988) 27.

[58] M. Bowker, P. Pudney, G. Roberts, J. Chem. Soc., Faraday Trans. 185 (1989) 2635. 